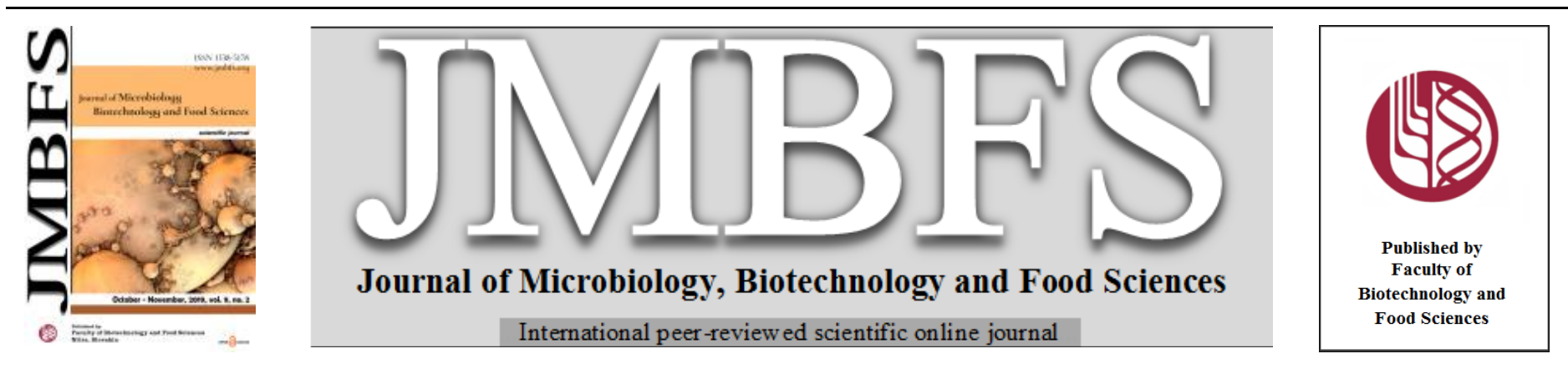

\title{
PLANTS' INNATE DEFENCE MECHANISMS AGAINST PHYTOPATHOGENS
}

\author{
Hakeem Olalekan Shittu ${ }^{l}$,Ebehi Aisagbonhi ${ }^{2}$ and Onyemaechi Henry Obiazikwor ${ }^{l *}$

\begin{abstract}
Address(es):
${ }^{1}$ Department of Plant Biology and Biotechnology, Faculty of Life Sciences, University of Benin, Benin City, Nigeria.
\end{abstract} \\ ${ }^{2}$ Physiology Division, Nigerian Institute for Oil Palm Research (NIFOR), Benin City, Nigeria.
}

*Corresponding author: onyemaechi.obiazikwor@uniben.edu

doi: 10.15414/jmbfs.2019.9.2.314-319

\section{ARTICLE INFO}

Received 14. 2. 2019

Revised 14. 6. 2019

Accepted 20. 6. 2019

Published 1. 10. 2019

\section{Review}

OPEN $\partial_{\text {ACCESS }}$

\begin{abstract}
Plants are affected by a number of severe conditions including damages caused by phytopathogens, which ultimately reduce productivity. Overtime, plants have evolved different mechanisms for defence against and resistance to invading pathogens, such as bacteria, viruses and fungi in different pathosystems. Defence mechanisms in plants could either be innate or artificial. Innate defence is said to occur when plants are naturally able to limit the development of a specific pathogen or the damage it may cause based on properties inherent in the plant without human intervention. This defence strategy could be divided into pre-existing and induced defence mechanisms. The pre-existing defence strategy comprises defence gardgets endogenously present in the plant even before pathogen colonization. It include the use of superficial structures (such as thick walled tissues, waxes and cuticle), biochemical substances (such as inhibitors released by plant into its environment) and defence through lack of essential factors (such as lack of host receptors and sensitive sites for toxins). The induced defence mechanism only becomes active in response to pathogen attack. It consists of defence through the formation of structures (such as cytoplasmic and cellular defence structures) and through biochemical reactions or the production of certain substances (such as pathogenesis related proteins and phenolics). Proper understanding of plant defence mechanisms against pathogens is important in developing new and improved disease resistant varieties.
\end{abstract}

Keywords: Phytopathogen, Resistance, Innate defence, Defence structures, Biochemical reactions

\section{INTRODUCTION}

Plants are organisms that are permanently exposed because of their sessile nature to harsh conditions including attack from pathogenic organisms such as bacteria, fungi, viruses and nematodes. They have overtime, developed multiple layers of defence mechanisms that recognize potentially dangerous pathogens (Freeman and Beattie, 2008). Plants are able to activate and use array of defences to ward off and be protected from attacks (Shittu et al., 2017) and damages caused by pathogens (Okungbowa and Shittu, 2012). Pathogens in turn may respond by suppressing or escaping plant defence responses or by rendering these responces ineffective (Shittu and Obiazikwor, 2018).

Plant defence mechanisms consist of a variety of preformed barriers: like cell walls, bark and cuticles (Laura et al., 2015). The barriers, give rigidity and strength to the plant in addition to protecting the plant from pathogen invasion. Apart from having barriers, plants also have the ability for defence against invading pathogens by responding with inducible defences which include the production of enzymes that degrade pathogens, toxic substances, and promote cell death (Sauban et al., 2016). Plants usually wait until they detect attacking pathogens before producing proteins or toxic substances involved in resistance because the cost of energy and nutritional requirements associated with their production and maintenance is high (Freeman and Beattie, 2008). The ability of plants to exclude attack from pathogenic or disease causing organisms by eliciting defence responses is termed plant disease resistance.

\section{PLANT DISEASE RESISTANCE}

The ability of a plant variety to limit the growth and development of a specific pathogen or the damage it may cause when compared to a susceptible variety, under common environmental conditions and pathogen pressure is known as plant disease resistance (Dixon $\boldsymbol{e t}$ al., 1994). The three types of resistance that occur in plants are non-host resistance, polygenic (quantitative or horizontal) resistance, and race-specific (monogenic, R gene, or vertical) resistance (Agrios, 2005). Depending on the type of resistance, the reaction of the plant to pathogen attack varies (Figure 1).

The type of resistance a plant exhibits when it is attacked by a pathogenic organism which is otherwise not the host of that pathogen is known as non-host resistance (Heath, 2001). For instance, the potato late blight pathogen does not infect apple or wheat plants and the apple pathogen, V. inaequalis, does not attack potato (Sauban et al., 2016). Also, the fungus, Blumeria (Erysiphe) graminis f. sp. Tritici, the causal agent of powdery mildew disease on wheat does not infect barley and the fungus, $B$. graminis f. sp hordei which produces same disease on barley does not infect wheat (Singh, 2005).

Resistance that is dependent on many genes for the formation of different preexisting or induced chemical substances or defence structures is said to be quantitative or polygenic. The genes of the pathogen become activated and release pathogenic enzymes, toxins, etc., against the host plant (Dangl and Jones, 2001). Most plants show resistance to such pathogen attack by possessing the ability to completely or partially defend such invasion using a combination of pre-existing or induced toxic substances or defence structures. Defence by several plants against pathogens e.g., the semibiotrophic oomycyte, Pythium, the fungus, Botrytis and most bacteria and nematodes, depend on polygenic resistance (Agrios, 2005).

Race-specific resistance involves the presence of a pair of complementary resistant and avirulent genes for disease in the host plant and pathogen respectively (Luderer and Joosten 2001). The host plant carries a resistant (R) gene while the pathogen carries a matching avirulence (Avr) gene (Dangl and Jones, 2001). The avirulence protein activates the $\mathrm{R}$ protein of the host plant, resulting in a sequence of defence reactions that annihilates the pathogen carrying the avirulence gene (Luderer and Joosten 2001). Race-specific resistance occurs in many host plants against various biotrophic oomycetes, fungi (e.g., Cladosporium), nematodes, viruses and many bacteria (Agrios, 2005). 


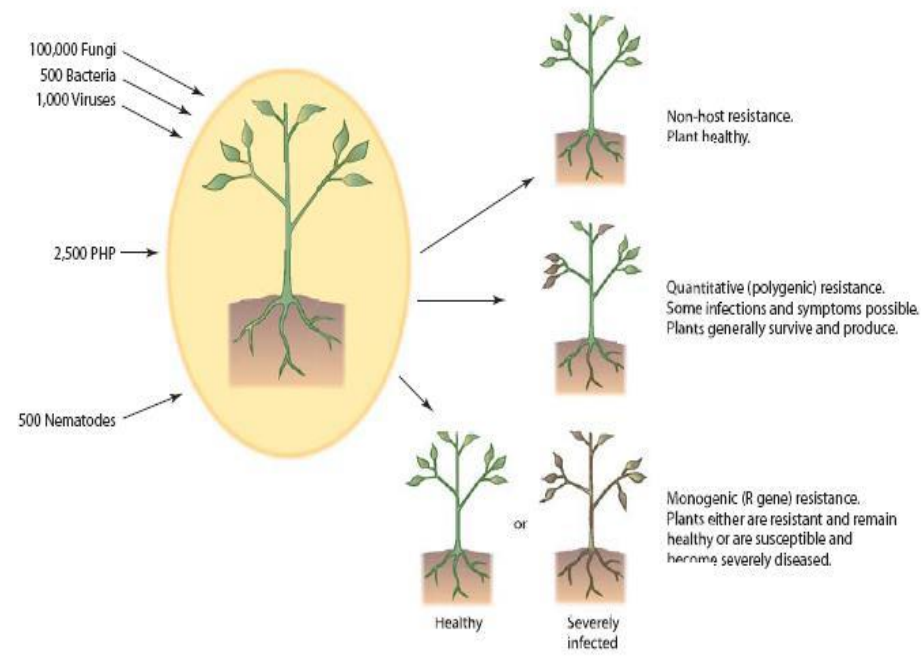

Figure 1 Types of reactions in plants to attack by a range of pathogens in relation to the kind of resistance of the plant (Agrios, 2005)

\section{PLANT DEFENCE MECHANISMS AGAINST PHYTOPATHOGENS}

Plants employ a combination of mechanisms for defence against pathogens in different host pathogen-systems. These defence mechanisms may be grouped into innate and artificial defence mechanisms. The innate defence mechanism refers to the machineries which plants are naturally able to elicit against invading pathogens owing to their inherent characteristics, while the defence mechanism which plants use in response to pathogen attack after being manipulated or assisted by man is referred to as artificial defence mechanism (Agrios, 2005) This review therefore focuses on the innate defence mechanisms.

\section{INNATE DEFENCE MECHANISM}

There are two categories of innate defence mechanism, which may act during any stage of infection in plants and can occur simultaneously if the conditions are favourable, namely: the pre-existing and induced defence mechanisms.

\section{PRE-EXISTING DEFENCE MECHANISMS}

This is the defence mechanism which forms the inherent basal first-line defence present within the plant even before pathogen colonization. It is grouped into the pre-existing structural defence mechanism, the pre-existing biochemical defence mechanism and defence through lack of essential factors.

a. Pre-existing structural defence mechanisms: This defence mechanism is made up of superficial structures often found on the plant surface, which generally present physical barriers to pathogen entry (Laluk and Mengiste, 2010). Pre-existing defence structures include:

i. Waxes and cuticles: Mixtures of long chain aliphatic compounds that form a water-repellent surface on the aerial parts of plants and prevent the formation of a film of water on plant surface essential for spore germination is known as waxes (Marcell and Beattie 2002). Pathogens such as fungi or bacteria are usually not deposited and thus will fail to germinate (fungi) or multiply (bacteria) when water film is absent (Horsfall, and Cowling, 1980). A chunky cuticle may enhance resistance to infection by effectively preventing pathogens which directly penetrate hosts but is not always correlated with resistance (Marcell and Beattie 2002).

ii. Epidermal cell walls: These are the first layer of living host cells; both specialized and unspecialized that come in contact with invading pathogens and form the first line of defence (Doughari, 2015). The epidermis comprises the outermost protective tissues of floral parts, fruits, seeds, stems, leaves and roots of plants until they undergo significant secondary growth. In woody plants, the periderm or outer bark replaces the epidermis on stems and roots and is often thicker due to the presence of high amounts of water resistant suberin. The presence of polymers like cellulose, hemicelluloses, lignin, polymerized organic compounds, etc., give hardness to the epidermis (Vance et al., 1980). Fungal pathogens find it difficult or impossible to directly penetrate the outer thicker and tougher walls of epidermal cells. However, if wounding occurs, inner tissues may be easily invaded. The walls though having same thickness may show variation in resistance to penetration by pathogen due to difference in toughness because of the presence or absence of lignin and silicic acid. For example, the lignified outermost wall of the epidermal cells of rice plants are seldom penetrated by Magnaporthe grisea, the causal agent of rice blast disease unlike the unlignified motor cell walls which are rather proteinaceous (Singh, 2005)

iii. Stomata and lenticels: Natural openings like stomata and lenticels allow the entry of many pathogenic bacteria and fungi into plants, although the structure of these openings may prevent the entry of pathogens in some cases (Cao et al., 2001). The resistance of the Szinkum variety of citrus to citrus canker bacterium is due to samll stomata and their very narrow openings surrounded by raised, broadlipped structures, which prevent the entry of water drops containing bacteria (Singh, 2005). The size and internal structure of lenticels possibly will also play a role for defence in plants against pathogens. Apple varieties possessing large-size lenticels on fruits easily allow the entry of Pseudomonas papulosum which causes leaf spot disease of apple but the varieties with small lenticels prevent the entry of the pathogen (Singh 2005)

iv. Thick-walled tissues: The cell walls of certain tissues inside the plant may become thickened due to environmental conditions. Such walls hinder the advance of pathogens. The vascular bundle or extended areas of sclerenchyma cells may prevent the further entry of pathogens in the stems of many cereal crops (Dixon et al., 1994).

b. Pre-existing biochemical defence mechanisms: This is the defence mechanism which involves different biochemical reactions in the plant cells or tissues even before pathogen invasion. These chemicals are capable of inhibiting or reducing infection by interfering with the activities of pathogens and pathogenesis (Doughari, 2015). These chemicals include:

i. Inhibitors exuded by the plant in its surroundings: Generally, plants give off organic substances via aerial surfaces and roots which accumulate in minute drops or diffuse into their environment. Some of these exudates are directly inhibitory to several pathogenic microorganisms or may promote certain microbial groups to take over the environment and act as antagonist to other pathogenic microorganisms (Dangl and Jones, 2016). For example, the red-scale varieties of onions which are resistant to onion smudge disease caused by Colletotrichum circinans, produce the fungitoxic exudates, protocathechuic acid and catechol, which inhibit the germination of the fungus and rupture the developing sperm tubes (Singh, 2005).

ii. Inhibitors present in the plant cell prior to infection: Inherent toxic substances in plants form the starting point of resistance in many host-parasite relationships (Leong et al., 2002). While these substances are present in large quantities in resistant varieties, they may be reduced or completely absent in susceptible ones. Several fatty acid compounds such as dienes and phenolics which pre-exist in high concentrations in cells are responsible for the resistance of young tissues to parasitic fungal genera such as Botrytis (Doughari, 2015). Many of these compounds are effective inhibitors of hydrolytic enzymes. Several other types of pre-existing compounds such as saponin, avenacin in oats and tomatine in tomato have antifungal membranolytic activity (Hammond-Kosack and Jones, 1997).

iii.

Plant proteins: Plants contain proteins e.g. lecitins, defensins, proteinases and amylases, which exhibit specific inhibitory effects on pathogenic enzymes by forming complexes that interfere with active sites or change enzyme conformations. This reduces the function of enzymes (Odjakova and Hadjiivanova, 2001). These proteins are usually small and very rich in the amino acid cysteine Unlike in the production of simple chemicals including phenolics, terpenoids and alkaloids (Facchini and St-Pierre, 2005), plants require a lot of energy to produce proteins and as a result, many proteins involved in plant defence are made in significant quantities only after pathogen attack. Once these proteins involved in defence are activated, they effectively inhibit bacteria, nematodes and fungi (Odjakova and Hadjiivanova, 2001). Several proteins involved in plant defence such as chitinases and ß- glucanases, also play crucial roles in the plant's development. these are induced in response to attack by herbivores, mechanical wounding, abiotic stresses, or during senescence (Castroverde $\boldsymbol{e t}$ al., 2010). It is often difficult to ascertain a specific role of such proteins involved in defence or resistance due to their multitasking functions. This is because many of the genes for which these proteins are encoded, belong to large gene families (Van Loon, 2006; Van Ooijin et al., 2007).

c. Defence through lack of important factors: Plants may lack some certain factors without which the pathogens are unable to successfully cause infection. Plant defence through lack of essential factors include the following:

i. Lack of recognition between host and pathogen: Plant host may lack certain specific molecules or structures that must be recognized by pathogens before they successfully infect the plant. 
There is a notion that various types of oligosaccharides, polysaccharides and proteins are involved in this defence mechanism but the actual factor is still unknown (Hutcheson, 1998).

ii.

Absence of host receptors and sensitive sites for toxins Most plant pathogenic fungi usually produce host-specific toxins These specific toxins require specific receptors on the host to be active. When a host lacks receptors and sensitive sites for toxins, no symptoms will be produced in the host after penetration by a toxin producing fungi (Hammond-Kosack and Jones, 1997)

iii. Lack of crucial substances for the pathogen: Most biotrophs and some facultative saprophytes, especially among fungi, are host specific and grow only on their single specific variety of hos (Sauban et al., 2016). This is believed to occur because such pathogens require certain substances which are only available in sufficient quantities in the host they infect. The absence of such substances in a host makes it a resistant variety to the pathogen. Only one example of this nature is well known. The seedling varieties susceptible to Rhizoctonia fungus contain a substance which initiates the formation of hyphal-cushion from which the fungus directs its penetration hyphae into the plant host but the resistant seedling varieties lack this essential substance and thus infection does no occur (Singh, 2005). A particular pathogen race may sometimes lose its ability to synthesize a certain substance due to mutation thus making the pathogen race non-pathogenic.

\section{INDUCED DEFENCE MECHANISMS}

This type of defence mechanism only becomes active after colonization by pathogens, and consist of two categories namely: the induced structural defence and the induced biochemical defence mechanisms.

a. Induced structural defence mechanisms

This mechanism involves the formation of structures which the plants are able to use to limit the spread of pathogens and the damages caused after colonization. The structures formed in this type of defence mechanisms may be cytoplasmic, cellular or histological. A necrotic structural defence reaction may also occur.

Cytoplasmic defence structures: The success of the entrance of a pathogen's hyphae into the cell of a particular hos through the penetration of the cell wall, results in the reorganization of the cell's cytoplasm in a manner that the cytoplasm becomes dense and granular with the development of certain organelle-like structure (Horsfall and Cowling, 1980). The penetrating hyphae thus disintegrate into smaller granular bodies and stop the further development of the hyphae. Cytoplasmic defence structures appear to be the last line of structural defence (Sauban et al., 2016). They are only effective against pathogenic fungi with slow growth that bring about chronic diseases or some form of symbiotic relationships such as mycorrhizae and root nodules of legumes (Singh, 2005).

ii. Cellular defence structures: The development of cellular defence structures including cell wall swelling and sheathing of advancing pathogen hyphae is a result of changes in the morphology and chemistry of the infected host cell wall.

inflammation of the cell wall: The outer wall of plants epiderma cells swells when they come in contact with penetrating hyphae. These swellings act by further inhibiting host penetration. Such a defence structure has been observed when pea leaves are attacked by Botrytis cinerea (Sauban et al., 2016). Sometimes, the swellings of the cell wall may be accompanied with deposits such as suberin and lignin thus becoming more resistant to penetration (Quiroga $\boldsymbol{e t}$ al. 2000). An example is the resistance of cucumber varieties to Cladosporium cucumerinum (Singh, 2005).

Sheathing of hyphae: It has been reported that the penetrating hyphae of pathogen, particularly fungi, often get enveloped in a sheath as a result of the inward stretching of the cell wall (Quiroga et al., 2000). The enveloped hyphae manage to penetrate the sheath and invade the cell cytoplasm. The sheathing serves to primarily delay the penetration, thus imparting partial check on the spread of the pathogen (Freeman and Beattie, 2008).

iii. Callose deposition: The deposition of callose, a $\beta-1,3-$ glucan, in a number of specialized wall or wall-associated structures This happens during normal plant development and also in reaction to wounding or attack by pathogen (Vance $\boldsymbol{e t}$ al., 1980).

iv. Histological defence structures: Tissue differentiation or deposition of chemical substances in tissues around the pathogens result in the formation of certain defence structures called histological defence structures. Defence through formation of histological structures include: abscission layer formation, cork layer formation, tyloses formation and gum deposition.
Abscission layer formation: Abscission layer develops to separate ripe fruits and old leaves from plants. An abscission layer is devoid of cells but consist of gaps between diseased and healthy tissues (Odjakova and Hadjiivanova, 2001). The gap is created by the dissolution of the middle lamella of one or two layers of cells surrounding the infected locus. The unsupported infected locus gradually shrivels, dies and falls off along with the pathogen as a result of the gap formation.

Cork layer formation: Pathogen attack in many hosts induces the formation of cork layers (Figure 2) below the point of infection which happens when certain chemicals secreted by the pathogen stimulate the host cells (Hutcheson, 1998). Further spread of pathogen beyond infected points is prevented by the cork layers. It also prevents the further spread of toxic substances produced by pathogens into the underlying tissues.

Tyloses formation: Outgrowths of the protoplast of adjacent parenchymatous cell extended into xylem vessels are known as tyloses (Sauban et al., 2016). The formation of tyloses obstructs the flow of water by blocking xylem vessels leading to plants developing wilt symptoms. In many plants however, the formation of tyloses is in response to attack by pathogens and brings about prevention from infection. For example, the fungus Fusarium oxyspora f.sp. batatas causes wilt disease in sweet potato but a resistant variety of sweet potato which quickly develops abundant tyloses ahead of the pathogen prevents its spread as the tyloses completely block the xylem vessels (Okungbowa and Shittu, 2011; Odjakova and Hadjiivanova, 2001)

Gum deposition: Many plants deposit gums along the border of infected tissue in response to pathogen attack. Deposited gum protects and demarcates infected from uninfected tissues as well as prevents the further spread of pathogen. Gum deposition has been found around lesions in leaves of rice varieties resistant to leaf spot and blast diseases of rice caused by Helminthosporium sp. and Magnaporthe grisea (pyricularia) respectively (Singh, 2005).

$v$ Necrotic structural defence reaction: This type of reaction occurs commonly when biotrophic fungal parasites, nematodes and viruses cause diseases in plants. Affected host cells and sometimes surrounding cells die quickly. The mechanism of the defence appears to be biochemical in nature but its consideration as a structural mode of defence is based on the fact that the necrotic tissue is ultimately responsible to check further spread of the pathogen (Freeman and Beattie, 2008). For instance, in wart disease of potato caused by Synchytriurn endobioticum, the nucleus of the host moves close to the pathogen when the pathogen is in contact with the protoplasm of the host cell. It soon disintegrates to form brown granules. These firstly, accumulate around the pathogen and then spread all over the cytoplasm of the cell. At the same time, the cell membrane becomes swollen, finally leading to the death of the cell. These events also affect the pathogen. As the nucleus disintegrates, the pathogen also disintegrates. This checks the spread of necrotic cells as the pathogen fails to grow out of such dead cells (Leong et al. 2002).

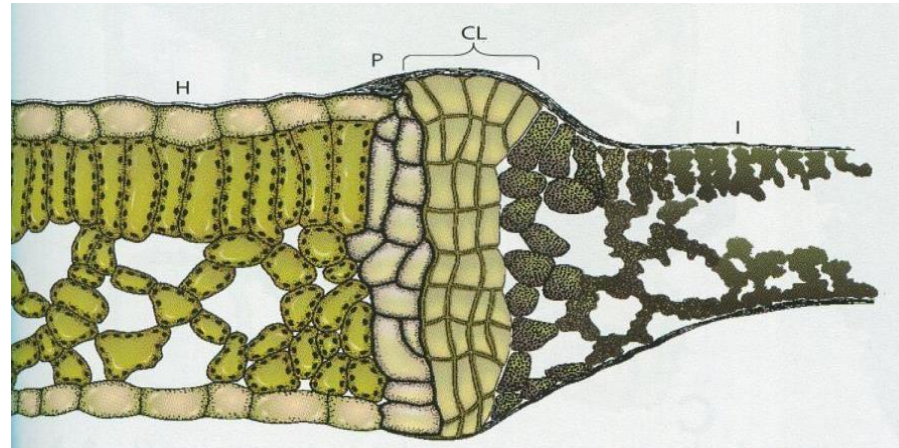

Figure 2: Cork layer formation in leaf tissue. (CL) cork layer $(\mathrm{H})$ healthy area (I) infected areas (P) phellogen (Agrios, 2005)

b. Induced biochemical defence mechanisms

This kind of defence mechanism involves the production of chemical substances in response to pathogen attack. These substances may either have toxic effect on pathogens or may counteract the effect of pathogen toxins. The induced biochemical defence mechanisms include the following:

i. Plant's detoxification of pathogen toxins: In resistan varieties of plants that become diseased as a result of toxins produced by the pathogens, released toxins are detoxified by metabolic processes of the host. For example, Magnaporthe grisea releases the toxins, pyricularin and picolinic acid, inside the host while causing 
rice blast disease (Singh, 2005). The resistant varieties unlike the susceptible ones, are able to convert about $40-60 \%$ of picolinic acid into its methylester and $\mathrm{N}$-methylpicolinic acid, and pyriculain into other compounds which are not toxic to the host plants (Singh, 2005).

Production of pathogenesis-related (PR) proteins: The proteins produced by plants in response to infection by pathogens are known as PR proteins (Shittu et al., 2009; Robb et al., 2009). they are associated with the development of systemic acquired resistance (SAR). Van Loon and Van Strien (1999), classified PR-proteins into 14 families. Most PR proteins have a destructive action on the parasite stuctures (Odjakova and Hadjiivanova, 2001). The PR-proteins with chitinase or $\beta$-1,3-glucanase activity for instance, can inhibit fungal pathogens by attacking the chitin and glucans which constitutes majority of the fungal cell walls. Apart from PR proteins, accumulation of small peptides with antimicrobial activity , such as thionins, defensins and lipid transfer proteins in infected plants (Rivas and Thomas, 2005) also form components of the induced defence system (Bergey et al., 1996; Broekaert et al., 1997; Fritig et al., 1998).

The antifungal properties of the very widely studied PR-1 proteins have been reported (Nidermann et al., 1995), and yet, the main function of these family of proteins remains unknown. As shown by Pieterse et al. (1996) in Arabidopsis and Hoffland et al. (1995) in radish infected with rhizobacteria and in tomato plants infected with Phytophthora capsici (Hong and Hwang, 2002), most PR-1 proteins may perform accessory roles but are not absolutely essential in resistance. The PR-2 proteins which comprise class I, II and III $\beta$ glucanases were first isolated from tobacco (van Loon and van Kammen, 1970), although, they have also long been reports on their discovery in several other plants. Many PR-2 proteins known to possess antifungal properties have been isolated from tomato (Domingo et al., 1994; Real et al., 2004). The genes that code for these proteins have also been shown to be activated in a coordinated manner during plant defence (Real et al., 2004). Some of the PR-2 proteins, as with many proteins implicated in plant defence, have also been shown to perform significant roles in plant development (Lotan et al., 1989). These comprise class I, II, IV, V, VI, and VII endochitinases PR proteins. The expression of chitinases appears to be regulated temporally and spatially (Yeboah $\boldsymbol{e t}$ al., 1998; Baty $\boldsymbol{e t}$ al., 2000). The PR-4 proteins are antifungal win-like proteins that possess endochitinase activity (Linthorst et al., 1991).

The PR-5, PR-13 and PR-14 are membrane interacting PR protiens (Castroverde et al., 2010). PR-5 proteins are antifungal, thaumatinlike proteins, including osmotin and they have been reported in tomato (Pressey, 1997; Jia et al., 1999, Robb et al., 2009). According to Vigers et al., 1991, increase in the levels of thaumatin proteins seem to produce antimicrobial effects that inhibit hyphal growth and sporulation. The PR-12 proteins belong to a group of protein called defensins. Examples of PR-12 proteins are the snakin antimicrobial peptides (Segura et al., 1999; Sels et al., 2008). Physiological functions proposed to be performed by these protein include the disruption of microbial membranes and they also play role as ligands during signal transduction (Thomma et al., 2003; Thevissen et al., 2004). The PR-13 proteins are a group known as thionins (Castroverde $\boldsymbol{e t}$ al., 2010). Thionins are toxic to a vast range of fungi and bacteria. They target the plasma membrane of these organisms although their exact mode of action is not certain (Stec, 2006). The PR-14 proteins comprise non-specific lipid transfer proteins which are encoded by a large multi gene family. They differ in their amino acid sequence, expression and anticipated functions (Blein et al., 2002)

iii. Production of phenolics: Plants cells or tissues mainly synthesize phenolics, in response to infection or injury. Phenolics are compounds which contain one or more benzene rings and hydroxyl groups respectively (Bergey et al., 1996). Phenolic compounds are synthesized in plants through the shikimic acid pathway or the acetic acid pathway (Gorlach $\boldsymbol{e t}$ al., 1995). In barley, branch points down stream of the shikimic acid pathway that result in the biosynthesis of aromatic amino acids, have been shown to be mediated by chorismate synthase, alongside chromate mutase and anthranilate synthase (Hu et al., 2009). The up regulation of the genes that encode the aromatic amino acids perform a role in preventing the penetration by Blumeria graminis f. sp. Hordei, the causative agent of powdery mildew (Hu $\boldsymbol{e t}$ al., 2009). Phenolics are classed into simple phenolics and toxic phenolics.

- $\quad$ Simple phenolic compounds: These are common phenolic compounds which pre-exist in healthy plants but their synthesis is accelerated when pathogens infect a healthy plant. Their concentration in the plant before a pathogen attacks is not enough to prevent infection but when a pathogen infects the plant, the plant rapidly accumulates these compounds adjacent to infection site or accelerate the flow of pre-existing amount from healthy tissues towards infected ones (Fritig et al., 1998). Simple phenolic compounds include chlorogenic acid, caffeic acid, scopoletin, isocumarin etc. (Hutcheson, 1998)

- Toxic phenolic compounds: Unlike simple phenolics which pre-exist in certain amounts in healthy plants, some toxic phenolic compounds, mainly phytoalexins, are only produced in response to pathogen attack (Hammerschmidt, 1999). Phytoalexins are isoflavonoids with antifungal and antibacterial properties (Nicholson and Wood, 2001). These toxic substances interrupt the metabolism or cellular structure of pathogens but frequently possess specific pathogen toxicity (Hammerschmidt, 1999). Examples include medicarpin, camalexin produced by alfalfa (Medicago sativa), Arabidopsis thaliana respectively, and rishitin produced by both tomatoes and potatoes (Freeman and Beattie, 2008).

iv. Hypersensitive response (HR): This is a kind of localized cell defence induced in the host plant at the spot of pathogen infection. HR, as shown in Figure 3, is a result of a sequence of defence responses by the affected and nearby cells and the successive release of toxic substance that often kill both the invaded and neighbouring cells as well as the pathogen (Agrios, 2005). The HR occurs only in host-pathogen interaction that are incompatible. It is often triggered when the gene products of a resistant gene $(\mathrm{R})$ in the plant cell recognize the presence of specific disease-causing effector molecules which are gene products of an avirulent gene, introduced by the pathogen into the host. Bacteria, viruses, fungi and nematodes are capable of inducing hypersensitive response in plants (Hutcheson, 1998). Oxidative burst is an important characteristic feature associated with the hypersensitive response during resistance (Harvey et al., 2008).

v. Production of reactive oxygen species (ROS) lipoxygenases and disruption of cell membrane: Changes in cell membrane results from pathogen attack or exposure to pathogen enzymes and toxins (Dangl and Jones, 2001). Some of these changes play active role in the defence against pathogen invasion. The release and accumulation of (ROS) and of lipoxygenase enzymes is an important membrane associated defence response. The rapid generation of superoxide, hydrogen peroxide and hydroxyl radical, which are harmful to invading pathogens, is one of the earliest events observed in host cells during host-fungus interactions (Freeman and Beattie, 2008). Activated oxygen seems to be implicated in normal or HR-induced cell death (Shirasu and Schulze-Lefert, 2000). They affect the membranes and cells of the invading pathogen either directly or indirectly through the (HR) of the host cell (Agrios, 2005). The released radicals may also cause injury to the host plant. Hydrogen peroxide, for example, is a free radical which is antimicrobial in nature. Its accumulation is harzardous to plant cells. The presence of the plant enzyme catalase, usually located in the peroxisomes of plant cells, is therefore important to catalyse the conversion of hydrogen peroxide to water and oxygen (Alberts et al. 2002). The lipoxygenases catalyse the hydroperoxidation of unsaturated fatty acids to form hydroperoxides which are involved in cell wall disruption and HR-induced cell death of host and pathogens (Gilchrist, 1998).

vi. strengthening of host cell walls with reinforcement molecules: The cell walls of several plants that come in contact with an infecting fungus make or build up defence-related substances that reinforce the resistance of the wall to pathogen attack (Dangl and Jones, 2001). These defence-related substances include phenolic compounds like lignin and suberin, glycoproteins such as extensin that have high hydroxyproline, and mineral elements such as calcium and silicon (Odjakova and Hadjiivanova, 2001). Some of these substances act in response and cross-link with one another thereby giving rise to insoluble cell wall structures that detain the invading fungus and avert further disease development (Agrios, 2005). 


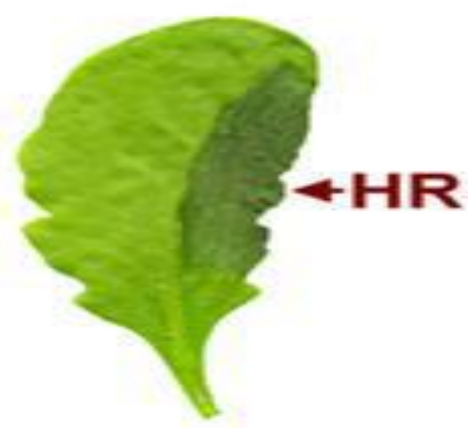

Figure 3: Hypersensitive response (HR) lesion on an Arabidopsis leaf (Freeman and Beattie, 2008).

\section{CONCLUSION}

Plants do naturally defend and resist pathogen attack, and manage to continue to grow and produce yields in appreciable amounts by employing a combination of structural features and biochemical reactions which may or may not be present in the plants throughout their lifetime. The innate basal line of plant defence which is constitutive within the plant may occur at any stage of pathogen invasion but may be affected by the plant's age, the type of organ affected, the nutritiona status of the host and environmental conditions. Proper understanding of plant defence mechanisms against pathogens is important in improving plan productivity and developing new and improved diseased resistant varieties Further researches in this area should be geered towards using recent genome editing techniques such as CRISPR/Cas9 to engineer crop plants for enhanced innate defence mechanisms against invading phytopathogens, thereby ensuring food security.

\section{REFERENCES}

Agrios, G. N. (2005). Plant pathology. Academic Press Incorporation, London. $922 \mathrm{p}$

Alberts, B., Johnson, A., Lewis, J., Raff, M., Roberts, K. \& Walter, P. (2002) Molecular Biology of the Cell (4th ed.). Garland Science, New York, NY. 1464 p.

Baty, A. M., Eastburn, C. C., Techkarnjanaruk, S., Goodman, A. E. \& Geesey, G. G. (2000). Spatial and temporal variations in chitinolytic gene expression and bacterial biomass production during chitin degradation. Applied Environmental Microbiology, 66, 3574-385.

Bergey, D. R., Howe, G. A. \& Ryan, C. A. (1996). Polypeptide signaling for plant defensive genes exhibits analogies to defence signaling in animals. Proceedings of the National Academy of Science 93, 12053-12058.

Blein, J. P., Coutos-Thévenot, P., Marion, D. \& Ponchet, M. (2002). From elicitins to lipid-transfer proteins: a new insight in cell signalling involved in plant defence mechanisms. Trends in Plant Science, 7, 293-296.

Broekaert, W. F., Cammue, B. P. A., De Bolle, M. F. C., Thevissen, K. Desamblanx, G. W. \& Osborn, R. W. (1997). Antimicrobial peptides from plants. Critical Review of Plant Science, 16, 297-323. https://doi.org/10.1080/07352689709701952

Cao, H., Baldini, R. L. \& Rahme, L.G. (2001). Common mechanisms for pathogens of plants and animals. Annual Review of Phytopathology, 39, 259-284. doi.org/10.1146/annurev.phyto.39.1.259

Castroverde, C. D. M., Nazar, R. N. \& Robb, J. (2010). Defence genes in tomato. Nova Science Publishers, New York. 82 p.

Dangl, J. L. \& Jones, J. D. G. (2001). Plant pathogens and integrated defence responses to infection. Nature, 411, 826-833. https://doi.org/10.1038/35081161

Dixon, R. A., Harrison, M. J. \& Lamb, C. J. (1994). Early events in the activation of plant defence responses. Annual Review of Phytopathology, 32, 479-501. https://doi.org/10.1146/annurev.py.32.090194.002403

Domingo, C., Conejero, V. \& Vera, P. (1994). A gene encoding acidic and basic class III beta-1,3-glucanses are expressed in tomato plants upon viroid infection. Plant Molecular Biology, 24, 725-732.

Doughari, J. (2015). An overview of plant immunity. Journal of Plant Pathology and Microbiology, 6 (02), 1-11.

Facchini, P. J. \& St-Pierre, B. (2005). Synthesis and trafficking of alkaloid biosynthetic enzymes. Current Opinion in Plant Biology, 8, $657-666$ https://doi.org/10.1016/j.pbi.2005.09.008

Freeman, B. C. \& Beattie, G. A. (2008). An Overview of Plant Defences against Pathogens and Herbivores. The Plant Health Instructor, http://dx.doi.org/10.1094/PHI-I-2008-0226-01\%20

Fritig, B., Heitz, T. \& Legrand, M. (1998). Antimicrobial proteins in induced plant defence. Current Opinion in Immunology, 10, 16-22. https://doi.org/10.1016/S0952-7915(98)80025-3
Gilchrist, D. G. (1998). Programmed cell death in plant disease: The purpose and promise of cellular suicide. Annual Review of Phytopathology, 36, 393-414 https://doi.org/10.1146/annurev.phyto.36.1.393

Görlach, J., Raesecke, H. R., Rentsch, D., Regenass, M., Roy, P., Zala, M., Keel, C., Boller, T., Amrhein, N. \& Schmid, J. (1995). Temporally distinct accumulation of transcripts encoding enzymes of the prechorismate pathway in elicitor-treated, cultured tomato cells. Proceedings of National Academy of Science, 92, 3166-3170.

Hammerschmidt, R. (1999). Phytoalexins: What have we learned after 60 years? Annual Review of Phytopathology, 37, 285-306. https://doi.org/10.1146/annurev.phyto.37.1.285

Hammond-Kosack, K. E. \& Jones, J. D. (1997). Plant disease resistance genes. Annual Review of Plant Physiology \& Plant Molecular Biology, 48, 575-607. doi:10.1146/annurev.arplant.48.1.575

Harvey J. J., Lincoln, J. E. \& Gilchrist, D. G. (2008). Programmed cell death suppression in transformed plant tissue by tomato cDNAs identified from an Agrobacterium rhizogenes-based functional screen. Molecular Genetics and Genomics, 279, 509 - 521. https://doi.org/10.1007/s00438-008-0329-2

Heath, M. C. (2001). Non-host resistance to plant pathogens: Nonspecific defence or the result of specific recognition events? Physiology and Molecular Plant Pathology, 58, 53-54. DOI: 10.1006/pmpp.2001/0319

Hoffland, E., Pieterse, C. M. J., Bik, L. \& Van Pelt, J. A. (1995) Induced systemic resistance in radish is not associated with accumulation of pathogenesisrelated proteins. Physiology and Molecular Plant Pathology, 46, 309 - 320.

Hong, J. K. \& Hwang, B. K. (2002). Temporal and subcellular localization of PR-1 proteins in tomato stem tissues infected by virulent and avirulent isolates of Phytophthora capsici. Protoplasma, 219, 131 - 139.

Horsfall, J. G. \& Cowling, E. B. (1980). Plant Disease (Vol. 5). Academic Press, New York. 436 p.

Hu, P., Meng, Y. \& Wise, R. P. (2009). Functional contribution of chorismate synthase, anthranilate synthase, and chorismate mutase to penetration resistance in barley-powdery mildew interactions. Molecular Plant Microbe Interaction, 22 311 - 320. https://doi.org/10.1094/MPMI-22-3-0311

Hutcheson, S. W. (1998). Current concepts of active defence in plants. Annual Review of Phytopathology, 36, 59-90. https://doi.org/10.1146/annurev.phyto.36.1.59

Jia, Y. \& Martin, G. B. (1999). Rapid transcript accumulation of pathogenesisrelated genes during an incompatible interaction in bacterial speck diseaseresistant tomato plants. Plant Molecular Biology, 40, $455-465$ https://doi.org/10.1023/A:1006213324555

Laluk, K. \& Mengiste, T. (2010). Necrotroph attacks on plants: wanton destruction or covert extortion? Arabidopsis Book 8:e0136 doi:10.1199/tab.0136.

Laura, M., Borghi, C., Bobbio, V. \& Allavena, A. (2015). The Effect on the Transcriptome of Anemone coronaria following Infection with Rus (Tranzschelia discolor). PLOS ONE 10(3): e0118565. 2015. https://doi.org/10.1371/journal.pone.0118565

Leong, S. A., Allen, C. \& Tripplett, E. W. (2002). Biology of Plant-Microbe Interactions (Vol. 3). Intern Soc Plant-Microbe Interactions, St. Paul, MN. 360 p. Linthorst, H. J., Danhash, N., Brederode, F. T., Van Kan, J. A., De Wit, P. J. \& Bol, J. F. (1991). Tobacco and tomato PR proteins homologous to win and prohevein lack the "hevein" domain. Molecular Plant Microbe Interaction, 4, 586 592

Lotan, T., Ori, N. \& Fluhr, R. (1989). Pathogenesis-related proteins are developmentally regulated in tobacco flowers. Plant Cell, 1, $881-887$. DOI: https://doi.org/10.1105/tpc.1.9.881

Luderer, R. \& Joosten, M. H. A. (2001). Avirulence proteins of plant pathogens: Determinants of victory and defeat. Molecular Plant Pathology, 2, 355-364. https://doi.org/10.1046/j.1464-6722.2001.00086.x

Marcell, L. M. \& Beattie, G. A. (2002). Effect of leaf surface waxes on leaf colonization by Pantoea aglomerans and Clavibacter michiganensis. Molecular Plant Microbe Interaction, 15, 1236 - 1244.

Nicholson, R. L. \& Wood, K. V. (2001). Phytoalexins and secondary products, where are they and how can we measure them?. Physiology and Molecular Plant Pathology, 59, 63-69. https://doi.org/10.1006/pmpp.2001.0344

Niderman, T., Genetet, I., Bruyère, T., Gees, R., Stintzi, A., Legrand, M., Fritig, B. \& Mösinger, E. (1995). Pathogenesis-related PR-1 proteins are antifungal Isolation and characterization of three 14-kilodalton proteins of tomato and of a basic PR-1 of tobacco with inhibitory activity against Phytophthora infestans. Plant Physiology, 108, $17-27$.

Odjakova, M. \& Hadjiivanova, C. (2001). The complexity of pathogen defence in plants. Bulgarian Journal of Plant Physiology, 27(01/02), 101-109.

Okungbowa, F. I. \& Shittu, H. O. (2012). Fusarium Wilts: An Overview. Environmental Research Journal, 6(2), $83-102$.

Okungbowa. F. I. \& Shittu, H. O. (2011). Vascular wilt of tomato caused by Fusarium oxysporum f. sp. lycopersici. In: Fusarium: Epidemiology, Environmental Sources and Prevention. TF Rios and ER Ortega (eds). Nova Science Publishers, Inc., USA. pp. 123-144, 2011.

Pieterse, C. M., van Wees, S. C., Hoffland, E., van Pelt, J. A. \& van Loon, L. C. (1996). Systemic resistance in Arabidopsis induced by biocontrol bacteria is 
independent of salicylic acid accumulation and pathogenesis-related gene expression. Plant Cell, 8, 1225 - 1237. DOI: https://doi.org/10.1105/tpc.8.8.1225 Pressey, R. (1997). Two isoforms of NP24: a thaumatin-like protein in tomato fruit. Phytochemistry, 44, 1241-1245.

Quiroga, M., Guerrero, C., Botella, M. A., Barceló, A., Amaya, I., Medina, M. I., Alonso, F. J., de Forchetti, S. M., Tigier, H. \& Valpuesta, V. (2000). A tomato peroxidase involved in the synthesis of lignin and suberin. Plant Physiology, 122, $1119-1127$.

Real, M. D., Company, P., García-Agustín, Bennett, A. B. \& González-Bosch, C. (2004). Characterization of tomato endo-beta-1,4-glucanase cel1 protein in fruit during ripening and after fungal infection. Planta, 220, $80-86$. https://doi.org/10.1007/s00425-004-1321-7

Rivas, S. \& Thomas, C. M. (2005). Molecular interactions between tomato and the leaf mold pathogen Cladosporium fulvum. Annual Review of Phytopathology, 43, 395 - 436. https://doi.org/10.1146/annurev.phyto.43.040204.140224

Robb, J., Castroverde, D. M. C., Shittu, H. O. \& Nazar, R. N. (2009). Patterns of defence gene expression in the tomato-Verticillium interaction. Botany, 87, $993-$ 1006. https://doi.org/10.1139/B09-056

Sauban, M., Jibril Bello, H. J., Ahmad, S. K. \& Harisu, Y. U. (2016). Plant and pathogens: pathogen recognition, invasion and plant defence mechanism International Journal of Current Microbiology and Applied Sciences, 5 (6), 247 257.

Segura, A., Moreno, M., Madueño, F., Molina, A. \& García-Olmedo, F. (1999) Snakin-1, a peptide from potato that is active against plant pathogens. Molecular Plant Microbe Interaction, $\quad 12, \quad 16 \quad-\quad 23$. https://doi.org/10.1094/MPMI.1999.12.1.16

Sels, J., Mathys, J., De Coninck, B. M., Cammue, B. P. \& De Bolle, M. F. (2008). Plant pathogenesis-related (PR) proteins: a focus on PR peptides. Plant $\begin{array}{lllll}\text { Physiolgy and Biochemistry, 46, } & 941 \quad-\quad 950\end{array}$ https://doi.org/10.1016/j.plaphy.2008.06.011

Shirasu, K. \& Schulze-Lefert, P. (2000). Regulators of cell death in disease resistance. Plant Molecular Biology, 44, 371-385. https://doi.org/10.1023/A:1026552827716

Shittu, H. O., Aghogban, O. N. \& Igiehon, E. (2017). Plant pathogen attack strategies. Journal of Phytopathology and Plant Health, 4(1) (In press).

Shittu, H. O., Castroverde, D. M. C., Nazar, R. N. \& Robb, J. (2009). Plantendophyte interplay protects tomato against a virulent Verticillium. Planta, 229, 415 - 426. https://doi.org/10.1007/s00425-008-0840-z

Shittu , H. O. \& Obiazikwor, O. H. (2018). Arms race between phytopathogens and host plants: A similitude of two nations at war. Journal of Microbiology, Biotechnology and Food Science 7(6): $646 \quad-650$ doi:10.15414/jmbfs.2018.7.6.646-650.

Singh, R. P. (2005). Plant Pathology. Kaylani publishers, New Delhi. 724 p.

Stec, B. (2006). Plant thionins-the structural perspective. Cell and Molecular Life Science, 63, 1370-1385. http://dx.doi.org/10.1007/s00018-005-5574-5

Thevissen, K., Warnecke, D. C., François, I. E., Leipelt, M., Heinz, E., Ott, C., Zähringer, U., Thomma, B. P., Ferket, K. K. \& Cammue, B. P. (2004). Defensins from insects and plants interact with fungal glucosylceramides. Journal of Biological Chemistry, 279, 3900 - 3905. doi: 10.1074/jbc.M311165200

Thomma, B. P., Cammue, B. P. \& Thevissen. K. (2003). Mode of action of plant defensins suggests therapeutic potential. Current Drug Targets- Infectious Disorder, 3, 1 - 8. https://doi.org/10.2174/1568005033342000

van Loon, L. C. \& van Kammen, A. (1970). Polyacrylamide disc electrophoresis of the soluble leaf proteins from Nicotiana tabacum var. "Samsun" and "Samsun NN". II. Changes in protein constitution after infection with tobacco mosaic virus. Virology, 40, $190-211$.

Van Loon, L. C. \& Van Strien, E. A. (1999). The families of pathogenesis-related proteins, their activities, and comparative analysis of PR-1 type proteins. Physiological and Molecular Plant Pathology, 55, $85 \quad-\quad 97$. https://doi.org/10.1006/pmpp.1999.0213

Van Loon, L. C., Rep, M. \& Pietersi, C. M. (2006). Significance of inducible defence-related proteins in infected plants. Annu Review of Phytopathology, 44, 135 - 162. https://doi.org/10.1146/annurev.phyto.44.070505.143425

Van Ooijin, G., Van der Burg, H. A., Cornelissen, B. J. C. \& Takken, F. L. W. (2007). Structure and function of resistance proteins in Solanaceous plants. Annual Review of Phytopathology, 45, $43-72$.

Vance, C. P., Kirk, T. K.\& Sherwood, R. T. (1980). Lignification as a mechanism of disease resistance. Annual Review of Phytopathology, 18, 259-288. https://doi.org/10.1146/annurev.py.18.090180.001355

Vigers, A. J., Roberts, W. K. \& Selitrennikoff, C. P. (1991). A new family of plant antifungal proteins. Molecular Plant Microbe Interaction, 4, 315 - 323.

Yeboah, N. A., Arahira, M., Nong, V. H., Zhang, D., Kadokura, K., Watanabe,

A. \& Fukazawa, C. (1998). A class III acidic endochitinase is specifically expressed in the developing seeds of soybean (Glycine max [L.] Merr.). Plant Molecular Biology, 36, 407-415. https://doi.org/10.1023/A:1005921104288 